\title{
PSYCHOTHERAPEUTIC INFLUENCE OF FOLKLORE ART THERAPY
}

\author{
Kutsyn E. K.
}

\section{INTRODUCTION}

Art therapy has recently attracted more and more attention around the world. It is, in a way, a method of treatment with the help of artistic creativity. For effective regulation of the emotional sphere of children, especially those with psychological problems, attention should be paid to their interests and needs. Learning requires constant attention from children, and therefore instills curiosity and produces diligence, patience and perseverance, forms and educates moral and ethical principles. Art lays the foundation of human character, such human qualities as friendliness, openness, commitment, which contribute to the saturation of life with bright moments ${ }^{1}$.

An important and priority task of society is to strengthen psychological, physiological, spiritual health, ensure full education and harmonious development of personality. Art therapy is a type of psychotherapy and psychological correction based on art and creativity. If we turn to the history of the development of creative therapy, we understand that it has historically consisted of independent actions, which were later combined into certain psychotherapeutic practices.

Due to the experience of individual moments that are carried out in the creative process, there is an opportunity to overcome a psychological problem or obstacle and resolve conflicts in an interesting and fun way. Art therapy can be represented by the following means of art: art, music, theater, etc. Any kind of art shows what cannot be conveyed in any other form. For example, the ancient Greeks thought that with the help of theater you can meet the gods.

Art therapy is one of the methods of psychological work, which uses the possibilities of art, including folklore, to achieve positive changes in intellectual, emotional and personal development. Elements of folk art therapy can be seen in ancient healing rituals and theatrical performances of many civilizations ${ }^{2}$. Ritual, one of the oldest art forms, gives people the opportunity to strengthen their faith and relationships, to rethink the theme of good and evil, using symbols and images that affect both individuals and groups of people.

\footnotetext{
${ }^{1}$ Назарова Л. Д. Фольклорная арт-терапия. Санкт-Петербург. 2002. С. 64.

${ }^{2}$ Газолишин В. Арт-терапія: Мистецтво бачити. Херсон, 2007. С. 12.
} 
All components of art - voice, movement, role improvisation, work with the text and the performance itself, along with the use of masks, costumes, lighting and staging, are integral components of folk art therapy. During the creative process, the body, mind and heart harmonize. In folklore, topics close to each person are touched upon, they act as a means of studying the life of an individual or an entire family.

Understanding folklore art therapy is based on the ability of a person not only to perceive, but also to reproduce what does not exist in reality. This is the most important principle of effectiveness, regardless of whether it is used for prevention or therapy.

\section{Folklore art therapy as a means of psychocorrection of the emotional state of a child}

Art therapy is a natural and careful way of treatment and development of the soul through artistic creativity, which has been actively developing as a set of psychotherapeutic techniques since the 1940's under the auspices of analytical psychology of K. G. Jung ${ }^{3}$. Areas of art therapy generally correspond to the kinds of art, and the variety of techniques is almost unlimited.

The properties of art therapy are as follows:

- it helps to express aggressive feelings in a socially acceptable form;

- it facilitates the expression of subconscious conflicts and inner experiences through visual images;

- it promotes the establishment of positive relationships with the psychotherapist and with each other;

- It allows sublimating negative energy into creativity.

Currently, there are several areas of use of art in the context of health, art therapy (art treatment):

- psychophysiological (correction of psychosomatic disorders);

- psychotherapeutic (impact on the cognitive and emotional spheres);

- psychological (performs cathartic (cleansing), regulatory, communicative functions);

- socio-pedagogical (development of aesthetic needs, expansion of general and artistic-aesthetic horizons, activation of potential opportunities of the teacher in practical artistic activity and creativity $)^{4}$.

The implementation of these areas on a practical level is carried out through certain psycho-correctional, correctional and developmental techniques used in art pedagogy and art therapy. Technologies of art therapy, according to a number of local and foreign researchers, are a set of

3 Валуйська А. Історія і види арт-терапії. Психолог. Шкільний світ. 2012. Лип. (№ 13/14). С. 66.

${ }^{4}$ Копытин А.И. Основы арт-терапии. Санкт-Петербург : Лань, 1999. С. 44. 
techniques that have differences and particular qualities that are determined by both genre affiliation to a particular art form, and orientation, methods of psycho-corrective treatment.

Let us consider the characteristic features related to art therapy:

- dialogues. With the help of art therapy a person feels the need to understand his or her own thoughts, understand the meanings and communicate with other people;

- openness of the purposes of work with the person as in the course of art therapy the person has unlimited opportunities for self-expression and self-realization;

- the internal logic of the development of the predicted quality is due to the fact that in real life a person experiences catharsis when meeting with art;

- influence on the integration characteristics of man, which determine the dynamics of the personal system as a whole. A person's emotional system is its integrative characteristic;

- individual and personal orientations of the teacher. Art therapy allows to develop not only personal qualities of the person, but also creates conditions for disclosure of its identity;

- bilateral effectiveness is due to the fact that catharsis is felt not only by the child but also by the teacher;

- the use of human capabilities as a pedagogical tool and sources in a concentrated form reflect a deep human problem;

- A man acts as a kind of a sign system. Catharsis is reflected in the external phenomena of man, emotions, movements, which allow people to understand and interact with each other;

- art therapy allows you to improvise in different arts. It should be noted that the use of art therapy is effective in working with any category of children ${ }^{5}$.

Recently, in the art-therapeutic environment, the so-called integration approach in therapy has become especially popular, when fine arts, theater, dance and music are used together for self-development and learning the secrets of one's own personality or to achieve specific psychotherapeutic goals.

On the example of musical folklore, syncretic in nature, we have a unique example of a holistic worldview, which, being accepted by the human soul, has a beneficial effect on it, ensuring, maintaining or building its integrity.

Folklore has the following features that can be used as an active pedagogical method of influence:

1) Establishing good relations. The non-directiveness of the method, the atmosphere of collective aesthetic experience, the involvement of all participants create an emotionally warm relationship;

\footnotetext{
${ }^{5}$ Копытин А.И. Основы арт-терапии. Санкт-Петербург : Лань, 1999. С. 86.
} 
2) Tension relief. In the course of folk games, dances, games there is a weakening and removal of the general tension;

3) Behavior change due to a new emotional experience. Each participant naturally "experiences" the emotional experience of previous generations;

4) Cognitive learning. The child not only participates in creative activities, but also receives information about ways to solve problems, acceptable ways of expressing feelings;

5) Acquisition and mastering of social skills and new forms of behavior. Improvisation allows trying different forms of behavior a sufficient number of times without fear of turning the process into a mechanical repetition;

6) Beliefs and suggestions 6 .

Folklore therapy is one of the ways to create a favorable psychological climate in the classroom and during extracurricular activities - it is a natural system of art therapy, which includes treatment with sound, movement, drama, drawing, color and contains hidden instructions to preserve the integrity of human personality. At the turn of the XX-XXI centuries, scientists have introduced the term "folklore therapy", which is defined as a direction of art therapy, in which the means of folklore is psychocorrectional and harmonizing effect on the individual ${ }^{7}$.

Folklore is considered as a subsystem of folk culture, as a complex of types of folk art. The use of folklore in classes, lessons and extracurricular activities involves an organic combination of various methods, techniques, due to the syncretism of the material and pedagogical conditions of its cognition. The focus is on the actual musical activity: performing, creative, listening, which creates an emotional connection between the participants. The work is carried out taking into account the age characteristics of students: their mobility, vulnerability, imagery of thinking, interest in play and learning activities, communication skills.

The idea of folk art therapy as an original direction, speaks of the inexhaustible creative potential inherent in each person and the possibility of using this potential to achieve mental health, inner well-being and harmony with others. Mutual support, self-confidence, self-development - these are all psychotherapeutic elements that fit organically into the structure of folklore.

\section{Methods of folklore art therapy}

Along with the study of certain states in folk art, there is a correction of certain traits of human character associated with undesirable phenomena for

\footnotetext{
6 Рудзик Е. Фольклор как фактор сохранения психического, физического и духовно-нравственного здоровья школьников. Музыкальная психология и психотерапия. 2010. № 2. С. 122.

7 Зыкова М.Н. Фольклор как средство психолого-педагогического воздействия на развитие самосознания и формирование самоидентификации школьника. Мир психологии. 2004. № 3. С. 42.
} 
society. Restraint, shyness, aggression are gradually disapear and become the opposite. On the physiological level, all negative emotions, which are the result of unwanted traits, cause breatholding, disrupt its rhythm, which cannot have a positive effect on the overall well-being of a person. Thus, as individual tasks become group-wide, then the movement of the whole group to the goal becomes a necessary condition for the development of the individuality of each of its members.

We will show the effectiveness of folk art therapy for children with deviant behavior. We define deviant behavior as a two-way process: on the one hand, deviant behavior is behavior in which a child for a number of reasons does not take into account in his life the norms and expectations of society, with adequate social perception of his individuality. In this case, it is necessary to change the child's attitude to the norms of social life. On the other hand, deviant behavior is the child's interaction with the social environment, which disrupts his/her development and does not take into account his/her individuality. In this case, you need to change the attitude of others toward the child.

Folk art therapy has a two-way process and two main mechanisms of influence:

1. Art allows reconstructing a traumatic conflict situation in a special symbolic form and finding its solution through the change of this situation on the basis of the creative abilities of a person.

2. Aesthetic reaction allows changing the effect from painful to pleasurable, to harmonize the inner world ${ }^{8}$.

In the course of creative activity the norms of behavior, interaction, expression of feelings are constantly reproduced and fixed. This is ensured by the repetition of formulas, rhythmic organization of methods and poetic texts.

Thus, folklore is one of the most effective methods of psychological and pedagogical influence, which can be applied to almost any problem that arises in working with children with developmental and behavioral disorders, promotes the child's natural adaptation to school and social environment.

The availability of methods of folk art therapy and the lack of contraindications allow it to be used for people of all ages and in any state of health. And children with their inherent play activities are happy to be creative: draw, sculpt, compose, paint. This pleasant and non-traumatic method is suitable for solving even the most hidden psychological problems.

Folk art therapy is indicated for working with children for a number of reasons:

- firstly, art therapy is based on working with images that represent a universal language, the organic nature of the child;

${ }^{8}$ Докторович М.О. Арт-терапія в діяльності психолога та соціального. Київ : Редакції загальнопедагогічних газет, 2014. С. 37. 
- secondly, therapy is based on spontaneity, which is completely natural for children;

- thirdly, folk art therapy is a projective method, especially convenient in working with children who are not able to verbally describe their condition (Zyikova, 2004, p. 37).

Images are a means of expressing unconscious needs and inclinations, internal conflicts, fears, protective reactions of the child.

The nature of the child is such that he/she will not lie to himself/herself, the child knows what he/she needs. And folklore in all its diversity has repeatedly demonstrated that it is a necessary part of education and adulthood. Introducing folklore into the school, we put along with other goals the following:

- involving students in the history and culture of their people;

- acquisition and awareness of the ancient roots of the genus;

- stimulating the growth of spirituality through examples of high folk art;

- teaching children the joy of their heart through the knowledge of the open sound;

- development of philosophical views on life with the help of the material used.

Younger students have a well-developed reproductive imagination. This feature of the child of primary school age is widely used by the authors of modern educational and methodical kits for the development of children's creative abilities, offering creative tasks: to supplement, complete, transform in their own way, to construct something new. When reproducing the image in the course of practical activities, the child develops imagination, the ability to think independently.

One of the features of children of primary school age is the high need for storytelling. The child listens to the sound of the word with pleasure, analyzes its sound composition and gives a description of sounds. This ability of children is taken into account by the authors of modern educational and methodical kits for the formation of oral and written speech ${ }^{9}$.

The textbooks provide tasks that facilitate the organization of educational dialogues, during which students express their views on the studied object, read in the fiction, etc.; tasks for the formation of the ability to work with different sources of information, reference books, use the capabilities of the computer, teaching themselves to look for answers to their questions; learning poems, participating in theatrical performances, games, that is dramatization, etc.

One of the areas of folk art therapy, the elements of which can be applied, is game therapy based on folk games. The game is a kind of "window" through which we can observe the development of children's

${ }^{9}$ Карсканова С.В. Психотерапія в роботі практичного психолога: навчальний посібник. Миколаїв. Іліон, 2018. С. 54. 
cognitive abilities and determine their level. In folk games, children get tactile sensations through physical contact, learn about the world around them. Games activate the formation of mental processes.

The game always evokes positive emotions. Also, the folk moving game, performing various functions (developmental, cognitive, entertaining, diagnostic, corrective) serves as a means of involving children in folk culture.

Thus, the use of folk art therapy in working with children of deviant behavior is effective, because it provides a two-way process:

- creating a pedagogically appropriate environment that takes into account the possibilities of child development;

- formation of the child as a subject of social life, taking into account the possibilities, norms, values of the environment, thus overcoming deviant behavior $^{10}$.

Involvement of a child in folk culture begins in childhood, where the basic concepts and examples of behavior are laid down. Cultural heritage is passed down from generation to generation, developing and enriching the child's world. Folklore is a unique means of transmitting folk wisdom and educating children at an early stage of their development. Folklore as a collective artistic creativity of the people has a clear didactic orientation. Much of it was created especially for children and was dictated by great care for young people, their future. Folklore "serves" the child from birth, develops the child's oral speech, affects its spiritual development, imagination.

Each genre of children's folklore teaches certain moral norms. For example, a fairy tale, by likening animals to humans, shows the child the rules of behavior in society, and fairy tales develop not only imagination but also intelligence. Proverbs and sayings teach children folk wisdom, which has been tested for centuries and has not lost its relevance in our time. The fables are aimed at fostering respect for the past of the people, the study of its traditions, the patriotism of the people who remained faithful to their homeland and defended it. Song lyrics also affect the upbringing of children. From ancient times lullabies, Christmas carols, etc. live in folk life.

Works created especially for children are a special area - children's folklore. Both theorists-educators and psychologists have repeatedly emphasized the high pedagogical qualities of folklore, which are addressed to children: deep penetration into the child's psyche, fine consideration of the peculiarities of children's perception, the absence of obsessive teachings. The closeness of folk art of childhood is characterized by great emotional strength and expressiveness of its images and determines the place of folklore in the education of children. Works of folklore provide great opportunities for aesthetic and moral education of students.

10 Зыкова М.Н. Фольклор как средство психолого-педагогического воздействия на развитие самосознания и формирование самоидентификации школьника. Мир психологии. 2004. № 3. С. 92. 
Educators use folklore therapy as one of the methods and techniques of health care. Under the health-preserving process of learning we understand the holistic educational process in the unity of the relationship of learning and education, characterized by joint activities, cooperation and co-creation of students, during which they not only receive education in accordance with state educational standard without harm to their health, but also have the ability to maintain and enhance health, that is there is a positive dynamics of quantitative and qualitative changes in physical, psychological, social capabilities of the person.

An essential characteristic of designing a healthy learning process at school is the process of creating conditions, using tools, forms, methods and technologies of learning that ensure the child's awareness of the value of their own health, education of health culture, development of healthy lifestyle skills.

In addition, there are ways to work with children with disabilities: tasks that involve the active use of gestures, sounds and facial expressions. Classes include genres of children's folklore, the value of which is that with its help a teacher or psychologist easily establishes emotional contact with the child, helps to understand the basics of folk culture, attracts to the national consciousness of the child. Several activities that are related to one plot are combined. Such classes do not tire children but arouse a lasting interest in learning and in music. Visual aids are used in the lesson; children are involved in practical activities ${ }^{11}$.

The structure of the lesson is aimed at achieving the goal, the lesson covers various activities. Tasks in the lessons are systematized by subject and difficulty levels. The class uses various forms of organization of educational activities (frontal, group, individual). The use of various methods, forms, teaching aids help to understand and formulate the rules of a healthy lifestyle, perform practical work, develop general skills and abilities, master the methods of activity, perform creative tasks.

The combination of verbal, visual, practical teaching methods allows ensuring the dominance of students' activity in the learning process, wider interaction of students with each other. The use of folklore allows making children interested in it and attracting their attention. Through musical games folklore therapy satisfies the child's need for communication and a sense of belonging to the class team, because this need is expressed in children since primary school. This method is the prevention of feelings of constraint, insecurity, loneliness and forms an adequate self-esteem, which in turn blocks the possibility of antisocial behavior of the student as a way of self-affirmation and overcoming communication difficulties.

11 Рудзик Е. Фольклор как фактор сохранения психического, физического и духовно-нравственного здоровья школьников. Музыкальная психология и психотерапия. 2010. № 2. С. 128. 
Folklore therapy affects not only the physiological development of the child, but also promotes the creation and development of intellectual, emotional and social functions of the child, helps the comprehensive development of personality. This technique is accompanied by psychoemotional relief, ensuring the creative and intellectual maturation of the child.

The use of folk therapy imitates social relations. At the same time there are real feelings, which represent a wide range of important emotions: friendliness, joy, compassion, empathy, a sense of unity and security, which form the emotional sphere of the child's personality. In the process of involving children in ethnocultural traditions, the use of folk therapy by observation, the improvement of children's emotional and physical condition, improvement of the psychological climate in the team was noted ${ }^{12}$.

Folk sound games, round dances, carols, ritual fragments contribute to the physical development of the child and have a significant health effect, especially in a situation of sitting with gadgets for hours, which leads to hypodynamics, not inherent in children's physiology. In general, after folk art therapy there is a harmonization of the psychophysiological state of children and a positive emotional impact.

Thus, folklore therapy has great educational potential. It arouses the interest of children, brings them feelings of joy, creates a good mood, relieves feelings of fear, anxiety, - in short, provides emotional and psychological well-being.

Art-therapy practices are the most effective forms of psychological care in crisis situations. The creative process becomes a psychotherapeutic mechanism for children, which allowed in a symbolic form to rearrange the conflict psychotraumatic situation, to form a new form of its solution. Through play, fairy tale, drawing, dancing, singing, there is the emergence of internal conflicts and strong emotions, which helps to understand their own feelings and experiences, helps to increase self-esteem and the development of creative abilities.

Nowadays art-therapy practices are the most effective forms of psychological care in crisis situations. Such classes are usually held in a relatively free form, without forcing the child to take any action, because the child does not think about the final outcome. He/she enjoys the process, feels free and enthusiastic about what is happening ${ }^{13}$.

The experience of practical application of the method of art therapy in working with children who have encountered crises and emergencies in their still short lives and formed fears and problems of behavior, has shown its effectiveness. Classes using art therapy methods help children cope with a traumatic situation, experience it on a new level, form new types of behavior, get rid of phobias, and adjust behavioral attitudes.

\footnotetext{
${ }^{12}$ Назарова Л. Д. Фольклорная арт-терапия. Санкт-Петербург. 2002. С. 177.
}

${ }^{13}$ Варій М.Й. Психологія особистості. Київ : Центр навч. л-ри, 2008. С. 172. 


\section{CONCLUSIONS}

In the pedagogical literature today there is the following definition: folklore is the richest and most developed art system, which is considered as a set of verbal, verbal-musical, musical-choreographic, game and dramatic works of folk art, where folk music, musical folklore is an integral part of folk art (folklore); a system that promotes the development of all senses, memory, attention, will, harmonize the relationship of the human person with the outside world, and is the basis for the formation of cultural and aesthetic perception of their people and other nationalities.

At present, integrative methods of restoring, strengthening and preserving physical and mental health are becoming increasingly popular, when fine arts, theater, dance and music are used for self-development and learning the secrets of one's own personality or to achieve specific psychotherapeutic, corrective, educational goals. Folklore includes all of the enumerated characteristic features:

1. Mutual support, self-confidence, self-disclosure and self-esteem - all these psychotherapeutic elements are present in the very structure of folklore.

2. There is a correction of certain personality traits. Restraint, shyness, aggression gradually disappear and turn into their opposite. Scandal and anger are so destructive that they are arrhythmic in our world, which is subject to different rhythms. They break the established harmony, dimension, beauty. On the physiological level, all negative emotions cause breatholding, disrupt its rhythm, which, of course, affects a person's general well-being, increases blood pressure and so on.

3 . There is an unconscious restoration of free breathing, blocked by various fears and limitations in the expression of feelings. In this way, the tension is relieved, children are cured of mistrust and doubt, fears, which previously seemed dangerous to them, and, consequently, feel better.

4. An important role in the positive orientation of the individual during folk art therapy is played by a peculiar manner of sound production, when the sound is sent into space, the lips are stretched in a smile, the front resonator is used. An external smile becomes an internal smile. In addition, observations show that those children who are engaged in folklore are less likely to suffer from infectious diseases.

5. Dance therapy as a means of non-verbal communication helps to solve both personal and internal problems. Developing emotional experiences in dance, group members help each other. Folklore, as a method of psychological and pedagogical influence can be applied to almost any problem that arises in working with children, promotes the natural adaptation of the child to the conditions of the school environment and social environment.

Adaptive educational system requires from each subject of selfgovernment and co-management the reflection on its activities (stimulation of 
internal efforts of the individual, his/her self-development). In practice, this becomes quite possible when mastering such pedagogical technologies as adaptive learning, collective and group teaching methods, education by means of folklore. It is the complex, harmonizing influence of musical folklore which allows us to conclude about the prospects of using this area in pedagogy.

The child, faced with the best examples of folklore and, above all, the music of his/her people, positively changes his/her behavior, becomes qualitatively different in his/her psychological state, calm and spiritually renewed. While communicating with folk art, he/she gets rid of emotional burnout, feelings of loneliness, fears, anxiety, naturally adapts to the social environment.

\section{SUMMARY}

Folk art therapy in modern conditions is necessary in the learning environment. It is through these tools that you can correct the psychoemotional state of children in a gentle, unobtrusive way. Research and testing of folk art therapy has been quite active in recent years, which once again indicate a gradual progress in the development of educational activities. Modern children, starting from preschool age, are in an altered emotional state, uncharacteristic of children also a few generations ago. Due to constant stress, exhaustion, the child's body does not cope with the modern rhythm, learning delays begin, which also affects the child's selfesteem and inner state. Such children begin to distance themselves from society and "close in on themselves". Folk art therapy is able to correct this situation, and respectively, is relevant in the means of using changes in the psychological state of the child.

\section{REFERENCES}

1. Валуйська А. Історія і види арт-терапії. Психолог. Шкільний світ. 2012. Лип. (№ 13/14). С. 66-67.

2. Варій М.Й. Психологія особистості. Київ : Центр навч. л-ри, $2008.592 \mathrm{c}$.

3. Газолишин В. Арт-терапія: Мистецтво бачити. Херсон, 2007. 75 с.

4. Докторович М.О. Арт-терапія в діяльності психолога та соціального. Київ : Редакції загальнопедагогічних газет, 2014. 97 с.

5. Зыкова М.Н. Фольклоротерапия : учебное пособие. Москва: МОДЭК, 2004. $160 \mathrm{c.}$

6. Зыкова М.Н. Фольклор как средство психолого-педагогического воздействия на развитие самосознания и формирование самоидентификации школьника. Мир психологии. 2004. № 3.

7. Копытин А.И. Основы арт-терапии. Санкт-Петербург : Лань, 1999. $256 \mathrm{c}$.

8. Копытина А. И. Арт-терапия - новые горизонты. Москва: Когито-Центр, 2006. 336 с. 
9. Назарова Л. Д. Фольклорная арт-терапия. Санкт-Петербург. 2002.

10. Карсканова С.В. Психотерапія в роботі практичного психолога: навчальний посібник. Миколаїв. Іліон, 2018. 151 с.

11. Рудзик Е. Фольклор как фактор сохранения психического, физического и духовно-нравственного здоровья школьников. Музыкальная психология и психотерапия. 2010. № 2. С. 122-130.

Information about the author: Kutsyn E. K., Senior Lecturer at the Department of Theory and Methods of Music Education

Mukachevo State University 26, Uzhgorodska str., Mukachevo, Transcarpathian region, Ukraine 